\title{
Sewage sludge ash (SSA) in high performance concrete: characterization and application
}

\section{Cinza de lodo de esgoto (CLE) em concretos de alto desempenho: caracterização e aplicação}
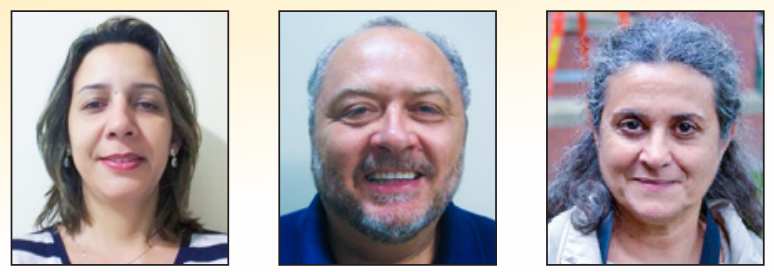

C. M. A. FONTES cintiafontes@gmail.com

R. D. TOLEDO FILHO b toledo@coc.ufrj.br

M. C. BARBOSA mclaudia@coc.ufrj.br

\begin{abstract}
Sewage sludge originated from the process of treatment of wastewater has become an environmental issue for three main reasons: contains pathogens, heavy metals and organic compounds that are harmful to the environmental and human health; high volumes are daily generated; and shortage of landfill sites for proper disposal. This research deals with the viability study of sewage sludge utilization, after calcination process, as mineral admixture in the production of concrete. High-performance concretes were produced with replacement content of $5 \%$ and $10 \%$ by weight of Portland cement with sewage sludge ash (SSA). The influence of this ash was analyzed through physical and mechanical tests. Analysis showed that the mixtures containing SSA have lower values of compressive strength than the reference. The results of absorptivity, porosity and accelerated penetration of chloride ions, presents that mixtures containing ash showed reductions compared to the reference. This indicates that SSA provided refinement of the pore structure, which was confirmed by mercury intrusion porosimetry test.
\end{abstract}

Keywords: sewage sludge ash, heavy metals, high-performance concrete, properties.

\section{Resumo}

O lodo de esgoto, proveniente do tratamento da fase líquida dos esgotos domésticos se tornou uma preocupação ambiental por três motivos principais: possui em sua composição patógenos, metais pesados e compostos orgânicos que são nocivos à saúde humana e ao meio ambiente; grandes volumes são gerados diariamente; e escassez de espaços para dispô-lo de forma adequada. A presente pesquisa tem por objetivo avaliar a possibilidade de aproveitamento deste resíduo, após processo de calcinação, como adição mineral na produção de concretos. Foram produzidos concretos de alto desempenho com teores de substituição de 5\% e 10\%, em massa, de cimento Portland por cinza de lodo de esgoto (CLE). Para avaliar a influência da cinza foram realizados ensaios físicos e mecânicos. Os resultados mostraram que as misturas contendo CLE apresentaram resistência à compressão inferior à referência. Em relação à absortividade, porosidade e penetração acelerada por íons cloreto, as misturas contendo cinza apresentaram reduções comparadas à referência, indicando que a CLE proporcionou refinamento da estrutura de poros comprovado pela porosimetria por intrusão de mercúrio.

Palavras-chave: cinza de lodo de esgoto, metais pesados, concreto de alto desempenho, propriedades.

Universidade Estadual de Feira de Santana, Departamento de Tecnologia, Programa de Pós-Graduação em Engenharia Civil e Ambiental, Feira de Santana, BA, Brasil; Universidade Federal do Rio de Janeiro, Programa de Engenharia Civil, COPPE, Rio de Janeiro, RJ, Brasil. 


\section{Introduction}

Sewage sludge is the solid part generated during the treatment of the liquid phase of domestic sewage. Given the large volumes produced in urban areas and the increase of restrictive laws imposed on its final disposal, the management of this by-product is of fundamental importance. In Brazil, an estimated annual output of between 150-220 tons of sludge [1], are most often simply disposed of in landfills or city "dumps", without any environmental control and usage perspective.

One possible use for this residue could be its application in agriculture, either as fertilizer or soil conditioner, because of its high organic matter content $(>50 \%)$ and phosphates and nitrogen in its composition [2]. However, the presence of pathogens, organic compounds and heavy metals is a limiting factor that contributes to adverse impacts on the environment (water, soil, flora and fauna) and thus restraining its use in crops of any kind.

Therefore, another technique is becoming more common, especially in industrialised countries with scarce land area: the incineration. Besides substantially reducing the sludge volume (about $85 \%$ of the original mass) and eliminating pathogens [3], its calorific value can be used to generate electrical or thermal energy during combustion, which is an interesting practice from the environmental point of view. Borges et al. [4] obtained a calorific value of $20 \mathrm{MJ} / \mathrm{kg}$ for sewage sludge, which is in the same order of magnitude as the eucalyptus wood briquette $(19,5 \mathrm{MJ} / \mathrm{kg})$ [5] and sugarcane bagasse $(19 \mathrm{MJ} / \mathrm{kg})$, residues widely used in boilers as alternative sources of renewable energy.

However, this type of process generates ashes that, dependingon the residue source, contain heavy metals and organic compounds in its composition, as in the case of calcined sewage sludge. An analysis performed on this type of sample detected the presence of $\mathrm{Cr}, \mathrm{Pb}, \mathrm{Cu}$, $\mathrm{Ni}$ and $\mathrm{Mn}$ in its constitution and similarities in chemical composition, even for residues coming from different WWTP's [6, 7, 8 and 9].

Although considered a heterogeneous residue the ash presents high levels of silica and alumina, the main compounds related to reactivity of the material, which has contributed to its use as a mineral addition in the production of mortars and conventional concretes $[3,6,10,11,12,13$ and 14]. Other studies have been carried out with this type of ash, and with that new materials have been produced and evaluated for their physical and mechanical behavior, including: lightweight and fine aggregates [15, 16, 17, 18, 19, 20], ceramics [21, 22 and 23] and concrete blocks [11].

Within this context, this paper aims at the utilization of the sewage sludge after the calcination process, as a partial replacement for Portland cement in concentrations of $5 \%$ and $10 \%$, by weight, in the production of high performance concrete. The selection criteria for this type of matrix was based on the type of microstructure that this concrete has when compared to conventional resistance concrete. That is, given the fact that SSA contains heavy metals in its composition even after the burning process, a dense microstructure turns more difficult for those compounds to solubilize into the environment [8].

\section{Materials}

\subsection{Portland Cement}

The cement used in this study was the CP II F-32, as there is no reactive mineral addition (pozzolans) in its composition, which may interfere with the SSA behavior. It has a density of $3.06 \mathrm{~g} / \mathrm{cm}^{3}$ and a compressive strength of $38.0 \mathrm{MPa}$ after 28 days.

\subsection{Sewage Sludge Ash (SSA)}

The sewage sludge used in this study was collected at "Alegria" wastewater treatment plant, located in the district of Caju, metropolitan area of Rio de Janeiro, where it was dehydrated by centrifugation, with the addition of polyelectrolytes.

Then, the material was physically characterized by the following aspects: moisture content NBR 6457 (ABNT, 1986), total solids and organic matter MF 436 (FEEMA, 1983), parameters required to evaluate the efficiency of burning of this material.

For burning temperature setting, the first criterion used was the high content of organic matter in the residue, which directly interferes in the cement hydration reactions and in the physical-mechanical behavior of the material. Based on the thermal analysis and thermogravimetry two burning temperatures $550^{\circ} \mathrm{C}$ and $650^{\circ} \mathrm{C}$ were defined [11]. Using the results of the analysis of possible gases emitted to the atmosphere during the sludge calcination process, performed by spectroscopy by fluorescence X-ray, it was found that for both temperatures SSA had the same chemical composition [3]. Based on the energy expenditure it was decided to burn sewage sludge at $550^{\circ} \mathrm{C}$, in a muffle furnace, with a heating rate of $10^{\circ} \mathrm{C} / \mathrm{min}$ and a residence time of 3 hours.

After the burning process, the SSA was milled using a porcelain rotational mill, with a capacity for 12 liters containing 6 liters of alumina grinding balls, and three liters of sample ash? per milling, for a period of 3 hours. This procedure was performed to meet the physical demands of NBR 12653 [24] for pozzolanic materials, which determines that the percentage retained in a $45 \mu \mathrm{m}$ sieve must be less than $34 \%$.

In order to evaluate the reactivity of SSA, there were conducted chemical and mineralogical characterizations, and pozzolanic activity index (IAP), according to NBR 5752 (ABNT, 1992) [25].

The chemical analysis was performed by energy dispersive $\mathrm{X}$-ray fluorescence spectroscopy, with a rhodium tube and $\mathrm{Si}$ (Li) detector, cooled with liquid nitrogen. The presence of heavy metals in the SSA was confirmed by $\mathrm{X}$-ray fluorescence spectrometer, semi automatic model, with silver tube of $30 \mathrm{~mA}$ and $40 \mathrm{~kW}$. These tests were conducted at the X-rays Laboratory of the National Center of Nuclear Energy (NCNE)/ Nuclear Energy Institute (NEI) of the UFRJ.

The mineralogy was obtained by $\mathrm{X}$-ray diffraction, by the powder method, with copper Ka radiation (30 kV / $40 \mathrm{~mA})$. Refinement by Ritivield with Ka radiation ( $40 \mathrm{kV} / 35 \mathrm{~mA}$ ) was used to obtain the amorphous content. Both tests were conducted in the Mineral Technology Center (MTC / UFRJ)

To evaluate the risk of the residue, an environmental analysis of the ash was conducted through tests of leaching NBR 10005 [26] and solubilization NBR 10006 [27]. Its classification was obtained according to NBR 10004 [28].

\subsection{Fine and coarse aggregates}

The fine and coarse aggregates were, respectively, river sand with $2.8 \mathrm{~mm}$ of fineness modulus, specific weight of $2.64 \mathrm{~g} / \mathrm{cm}{ }^{3}$ and water absorption of $1.23 \%$, and granitic gravel with maximum 
dimensions of $9.5 \mathrm{~mm}$, specific weight of $2.69 \mathrm{~g} / \mathrm{cm}^{3}$ and water absorption of $1.08 \%$.

\subsection{Chemical additive}

To maintain the same slump for all mixtures $(150 \pm 10 \mathrm{~mm})$ without changing the water/ binder ratio, a naphthalene sulfonated based superplasticizer (SP) chemical additive was used, with $42 \%$ of solids content.

\section{Experimental program}

The experimental program was developed in order to evaluate the influence of SSA on high performance concrete properties. Three mixtures were produced: reference (REF) aiming to reach a compressive strength of $60 \mathrm{MPa}$ at 28 days of age, SSA $5 \%$ and SSA $10 \%$, with levels of $5 \%$ and $10 \%$ of SSA as partial replacement of Portland cement, respectively. Table 1 shows the traces and materials consumption per $\mathrm{m}^{3}$ of concrete.

The concrete was produced in an acclimatized room with a temperature of $21^{\circ} \mathrm{C} \pm 2^{\circ} \mathrm{C}$ using a vertical axis planetary mixer, with effective capacity of 100 liters. The molding of the samples was performed in three layers, of which each was densified by a vibratory table with a rotation speed of $62 \mathrm{~Hz}$ for 30 seconds. Subsequently, the samples were covered with a moistened fabric for a period of 24 hours, to prevent water loss from the mixture,. After this period, they were demolded and kept in a humid chamber $(\mathrm{RH}=100 \%)$, until the appropriate age for testing. For each mixture 33 cylindrical samples were molded.

The ash behavior was evaluated by the following tests: axial compressive strength at ages of $1,3,7,28,91,180$ and 365 days, tensile strength by diametrical compression, water absorption, capillary water absorption, accelerated penetration of chloride ions and mercury intrusion porosimetry test at the age of 28 days. As there was not enough ash for the physical testing and durability test at older ages, it was decided to realize further testing and evaluate its behavior at the age of 28 daysonly, when almost all the concrete hydration had already occurred, serving as reference to the researchers.

\subsection{Methodology of the tests}

The compressive strength test was performed in a testing machine with a total load capacity of $1000 \mathrm{kN}$ for the ages of $1,3,7,28,91$, 180 and 365 days, using cylindrical specimens with $100 \mathrm{~mm}$ diameter and $200 \mathrm{~mm}$ height.

The longitudinal and transversal displacements were measured, respectively, by two electric transducers, diametrically opposed, in the central part of the sample and by an electrical transducer, located in the transversal axis of the sample, with a displacement rate of $0.01 \mathrm{~mm} / \mathrm{min}$.

This data was collected at ages of 28 and 91 days and used to plot the stress $x$ strain curve. At other ages only the load value was obtained using a speed of $0.1 \mathrm{~mm} / \mathrm{min}$. The compressive strength value for each mixture was the average of three samples per age, totalizing 21 samples.

The modulus of elasticity was calculated using the secant modulus for a stress of $40 \%$ of the limit stress of the stress $x$ strain curve [29] and Poisson's ratio from the ratio between the transverse and longitudinal deformations due to axial loading within the elastic limits. The tensile strength for diametrical compression (Rtcd) values was obtained after 28 days using discs with $100 \mathrm{~mm}$ diameter and 25 $\mathrm{mm}$ thickness, as ??method proposed for rocks [30]. The test was performed in a testing machine with a speed of $0.3 \mathrm{~mm} / \mathrm{min}$, being the Rtcd value for each mixture, the average of 10 discs. Discs were used in this test, because this methodology is used in the COPPE/UFRJ Structures Laboratory and presents the same behavior of the tensile test for diametrical compression. A total of 12 disks were cut from the central parts of three samples (4 discs per sample), of $100 \mathrm{~mm}$ diameter and $200 \mathrm{~mm}$ height. . Two were separated for use in the mercury intrusion porosimetry test.

The test of absorption by immersion was performed according to NBR 9778 [31], using cylindrical samples with dimensions of 100 $\mathrm{mm}$ diameter by $200 \mathrm{~mm}$ height, with the aim of obtaining the water absorption parameters, void ratio and specific weight for all mixtures. The test of absorption by capillarity was based on NBR 9779 [32], using cylindrical samples with the following dimensions: $75 \mathrm{~mm}$ diameter by $150 \mathrm{~mm}$ height, in order to obtain the mass gain of water in function of time. In this test all samples were sealed with plastic wrap, leaving free only top and bottom, according to Hall [33], in order to ensure unidirectional flow and prevent moisture loss. The test was conducted for a period of 986 hours for all the mixtures and the absorptivity of the material was calculated based on capillary flow theory in unsaturated material, where Hall [33] found that the cumulative water gain varies in function of the square root of the time. This parameter was obtained in stage 1 and 2 according to Figure 1.

The results for water absorption by immersion and capillarity were performed at the age of 28 days and the results are the average of three samples per test and mixture.

The mercury intrusion porosimetry test was performed at the age of 28 days. This method was used to characterize the internal structure of the material over the distribution of pore size. For this 6 cubic samples of $1 \mathrm{~cm}^{3}$ were extracted for each mixture from the remaining two disks of Rtcd, as previously explained. The tests were performed on ABCP/SP, using an Autopore II 9215

Table 1 - Consumption of materials for $1 \mathrm{~m}^{3}$ of concrete

\begin{tabular}{ccccccccc} 
Mixiures & Trace in mass & $\begin{array}{c}\text { Cement } \\
(\mathrm{kg})\end{array}$ & $\begin{array}{c}\text { SSA } \\
(\mathrm{kg})\end{array}$ & $\begin{array}{c}\text { Sand } \\
(\mathrm{kg})\end{array}$ & $\begin{array}{c}\text { Gravel } \\
(\mathrm{kg})\end{array}$ & $\begin{array}{c}\text { Water } \\
(\mathrm{kg})\end{array}$ & $\begin{array}{c}\text { SP* } \\
(\mathrm{kg})\end{array}$ \\
\hline REF & $1: 1,42: 1,49: 0,31$ & 566,94 & - & 805,05 & 844,74 & 175,75 & 5,10 \\
SSA5\% & $0,95: 0,05: 1,42: 1,49: 0,31$ & 537,87 & 28,31 & 803,98 & 843,61 & 175,51 & 5,10 \\
SSA10\% & $0,90: 0,1: 1,42: 1,49: 0,31$ & 508,88 & 56,54 & 802,90 & 842,48 & 175,29 & 7,35 \\
\hline
\end{tabular}




\section{Figure 1 - Typical graph of apparent mass increase as a function of square root of time. Source: (GONÇALVES, (34))}

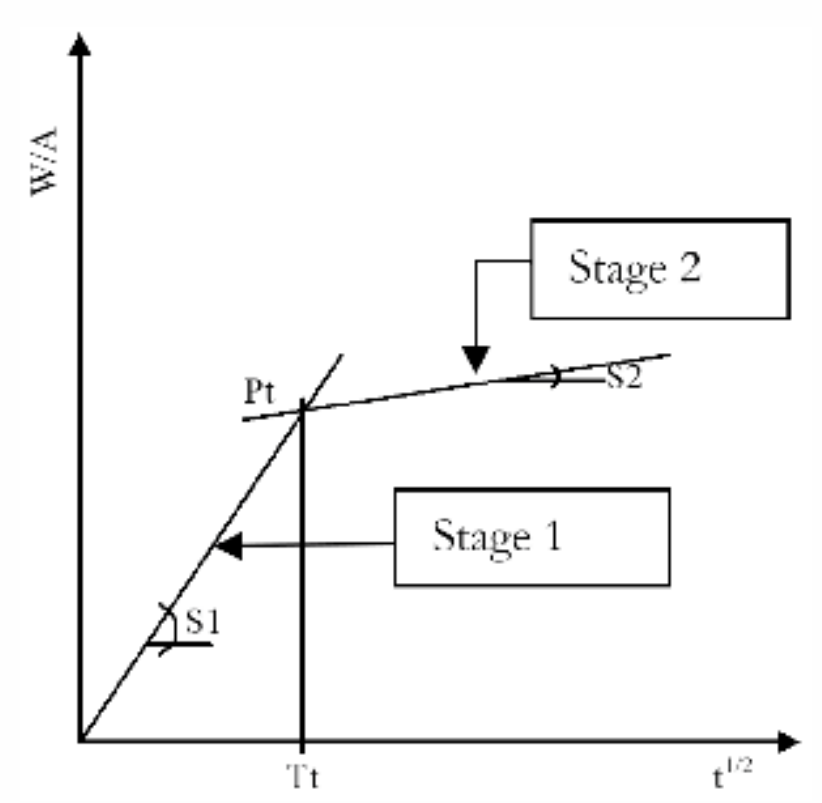

porosimeter, with contact angle between the solid and the mercury of $130^{\circ}$. The classification used in this study for the division of the pore system was according to Aligizaki [35].

The test of accelerated penetration of chloride ions is designed to measure the amount of electric current passing through a sample of $50 \mathrm{~mm}$ thickness and $100 \mathrm{~mm}$ in diameter when a potential difference of $60 \mathrm{~V}$ is applied between the electrodes. The test procedure was performed at 28 days, according to ASTM C 1202 [36]. The results were the average of three samples per mixture. As this is a high-performance concrete, it would have been desirable to conduct long-term tests to evaluate the physical properties and durability, as was done for the compressive strength property. However, this was not possible due to the low amount of SSA.

\section{Results and discussions}

\subsection{Sewage sludge ash}

\subsubsection{Levels of humidity, total solids and organic matter of sewage sludge}

The sewage sludge "in natura" presented results of $66.2 \%$ for moisture content, $37 \%$ for total solids and $54.7 \%$ for organic matter. These obtained parameters were important because they indicate the efficiency of burning of the material, that is, the content of fixed solids of approximately $17 \%$ compared to the initial mass of material remained after the calcination of the sludge. . It was possible to optimize the process of sewage sludge burning [3].

\subsubsection{Physico-chemical, mineralogical and environmental characterization of SSA}

Figure 2 shows the granulometry of cement Portland and SSA used in this research. The results show the similarity between these two materials, differing only, in the lower $10 \%$ cumulative passing, in which the cement presents smaller granulometry compared to the SSA. Even so, the SSA has $90 \%$ of its grain less than $45 \mu \mathrm{m}$ meeting the requirement of NBR 12653 [24] for pozzolanic materials. Its specific weight was $2.68 \mathrm{~g} / \mathrm{cm}^{3}$.

With regards to the chemical characteristics, presented in Table 2, it is found that SSA has not met the requirements of NBR 12653 [24] for the $\mathrm{SO}_{3}$ content, which was $6.38 \%$ (maximum of $4.0 \%$ ) for alkalis $^{*}$ content, which was $2.42 \%$ (maximum of $1.5 \%$ ). It is noteworthy, that the presence of these, above the required limit, will not be detrimental to the concrete due to the low cement replacement levels by mineral additives in this case ( $5 \%$ and $10 \%)$. Consequently, by not meeting the specifications of the standard for this item, the ash cannot be classified as pozzolanic material. However, the pozzolanic activity index of SSA was $91 \%$ higher than the required minimum of $75 \%$, which indicates the possibility of the material's reactivity .

Lima [6], using septic sludge ash found PAl values ranging between 61 and $66 \%$ for ash burned at 700,800 and $900^{\circ} \mathrm{C}$. Geyer [13] obtained values between 72 and $76 \%$ for ash burned at $800^{\circ} \mathrm{C}$, but with different granulometries. It can be said, therefore, that the burning temperature and the ash granulometry are parameters that directly affect the reactivity of this material.

Another factor shown in Table 2 is the similarity between the compounds present in the SSA with ashes from other authors, but in different concentrations $[6,7,8,9]$. This variation is directly associated with, among others, eating habits and the level of sanitation of the people portrayed in the origin of sewage and the type of treatment used [37, 38].

The presence of heavy metals such as chromium, copper, lead, nickel, barium, selenium and zinc in the ash composition of the present study and from other authors must also be highlighted. This is because even at reduced concentrations, these metals may solubilize into the environment, polluting it, being indicative of the need for safe disposal of the material, confirmed by environmental analysis, as SSA was classified as class II A residue - not inert.

In the mineralogical composition of SSA the presence of well - defined crystalline phases and a very heterogeneous composition was verified, matching the chemical analysis. The ratios were higher for the microcline $\left(\mathrm{KAISi}_{3} \mathrm{O}_{8}\right)$ and quartz $\left(\mathrm{SiO}_{2}\right)$, which have

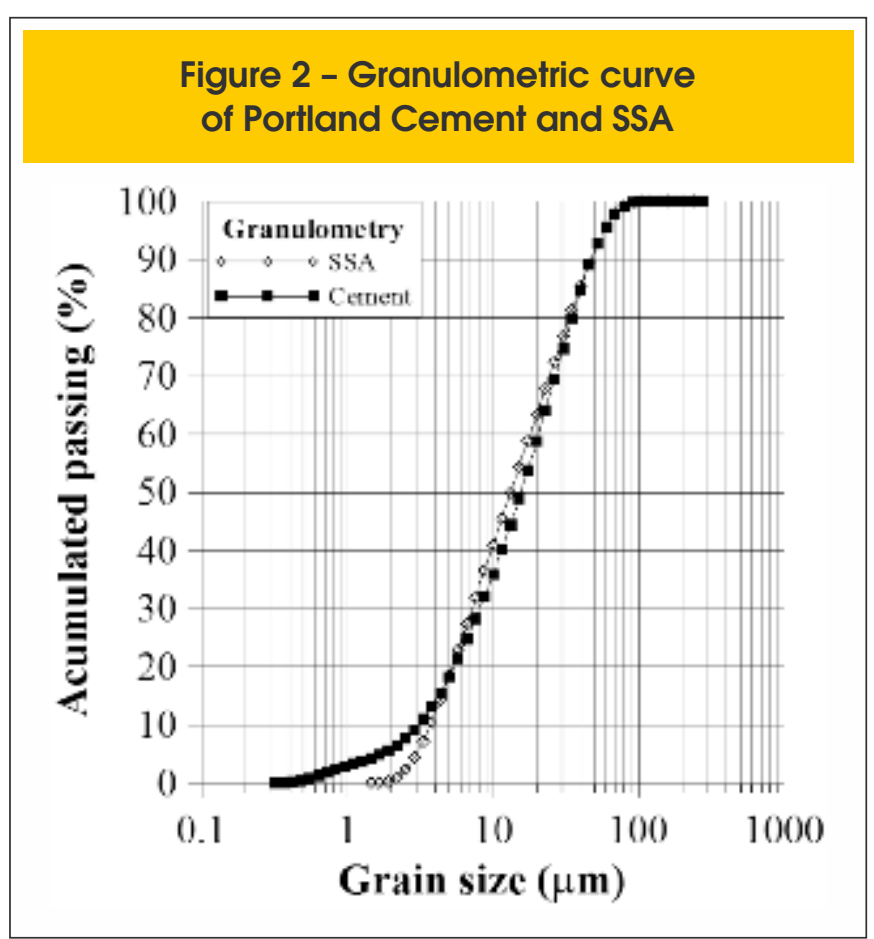




\section{Table 2 - Chemical analyses of SSA}

\begin{tabular}{|c|c|c|c|c|c|c|c|c|c|c|}
\hline \multirow{2}{*}{ Ashes } & \multicolumn{10}{|c|}{ Concentration (\%) } \\
\hline & $\mathrm{SiO}_{2}$ & $\mathrm{Al}_{2} \mathrm{O}_{3}$ & $\mathrm{Fe}_{2} \mathrm{O}_{3}$ & $\mathrm{CaO}$ & $\mathrm{MgO}$ & $\mathrm{P}_{2} \mathrm{O}_{5}$ & $\mathrm{SO}_{3}$ & $\mathrm{~K}_{2} \mathrm{O}$ & $\mathrm{Na}_{2} \mathrm{O}$ & $\mathrm{TiO}_{2}$ \\
\hline CLE & 39,02 & 19,09 & 12,48 & 10,12 & 1,89 & 4,94 & 6,38 & $1,76^{*}$ & $1,26^{*}$ & - \\
\hline (6) & 33,15 & 25,44 & 5,11 & 5,44 & 3,78 & 4,20 & 6,19 & 0,71 & - & 1,14 \\
\hline (7) & 34,2 & 12,6 & 4,7 & 20,6 & 1,9 & 14,8 & 2,8 & 1,7 & 1,0 & 0,9 \\
\hline (8) & 50,6 & 12,8 & 1,93 & 7,21 & 1,48 & 1,67 & 2,38 & 1,70 & 0,32 & - \\
\hline (9) & 17,27 & 9,64 & 8,52 & 30,24 & 3,22 & 14,25 & 8,95 & 1,28 & 0,94 & 0,92 \\
\hline \multirow{2}{*}{ Ashes } & \multicolumn{10}{|c|}{ Concentration (\%) } \\
\hline & $\mathrm{Cr}_{2} \mathrm{O}_{3}$ & Zno & $\mathrm{PbO}$ & CuO & $\mathrm{SeO}$ & $\mathrm{BaO}$ & $\mathrm{NiO}$ & $\mathrm{ZrO}_{2}$ & SrO & MnO \\
\hline CLE & 0,21 & 0,45 & 0,07 & 0,02 & 0,06 & 1,46 & 0,20 & - & - & 0,09 \\
\hline (6) & 0,03 & 0,35 & 0,01 & 0,09 & - & - & 0,01 & 0,03 & 0,01 & 0,04 \\
\hline (7) & 0,26 & 0,71 & 0,07 & 0,25 & - & 0,14 & 0,06 & - & 0,06 & 0,06 \\
\hline (8) & 0,564 & 2,62 & 0,18 & 1,09 & - & - & 0,72 & - & - & 0,44 \\
\hline (9) & 0,17 & 0,32 & 0,04 & 0,18 & - & 0,14 & 0,03 & - & 0,25 & 0,07 \\
\hline
\end{tabular}

in their composition the higher percentages of oxides present in the ashes, followed by anhydrite and talc, as counts per Ritivield [3]. The amorphous content present in the ash was $32 \%$, confirming the possibility of reactivity of this material.

\subsection{Reference concretes and with SSA}

Figure 3 shows the relative compressive strength charts in function of time.

The results show that at the age of 7 days, the degree of hydration of the mixture SSA $10 \%$ was lower than the REF and SSA $5 \%$. However, in more advanced ages this difference had been overcome, increasing additions of $4 \%$ and $2 \%$ with respect to the REF and SSA $5 \%$. For the mixture of $5 \%$ SSA, the degree of hydration was very close to that of the reference mixture for all ages. It can be assumed therefore, that substitution of Portland cement by $5 \%$ and $10 \%$ of SSA did not interfere with cement hydration reactions compared to the reference, since the values obtained for the three mixtures were very close.

In relation to the development of resistance to compression in time, shown in Table 3, it can be said that for $5 \%$ ash content, results were below the reference at ages of 1, 28, 91 and 365 days, varying between $4 \%$ and $7 \%$. For the SSA $10 \%$ mixture these reductions were more significant for all ages, with percentages ranging from $10 \%$ to the age of 365 days and $33 \%$ for 1 day.

It is known that the compressive strength reduction behavior, according to the porous structure of the material, is directly associated with pores larger than $0.05 \mu \mathrm{m}$. From the results of the mercury intrusion porosimetry test (Table 4), it appears that mixtures containing ash, presented an increase in the volume of mercury from large capillaries $(0.05<\phi<10 \mu \mathrm{m})$ as the ash content increase, demonstrating the presence of a larger amount of pores greater than $0,05 \mu \mathrm{m}$ compared to REF.

This same behavior was found by Tay et al. [12] Tay [22], Tay [23] in concretes containing SSA and by Cyr et al. [7] in mortars. That is, as the ash content in the mixture increased the compressive strength reduced in relation to the reference.

Figure 4 shows the tension $x$ deformation diagram. The elasticity modulus values obtained for mixtures with $5 \%$ and $10 \%$ SSA were very close to that of the reference mixture at both ages, as can be seen in Table 5. The small decrease observed for mixtures containing ash at 91 days, with the exeption of SSA $5 \%$ mixture, may be

Figure 3 - Compressive strength at $1,3,7$ and 28 days

(a) and at 1, 3, 7, 28, 91 and 365 days (b)
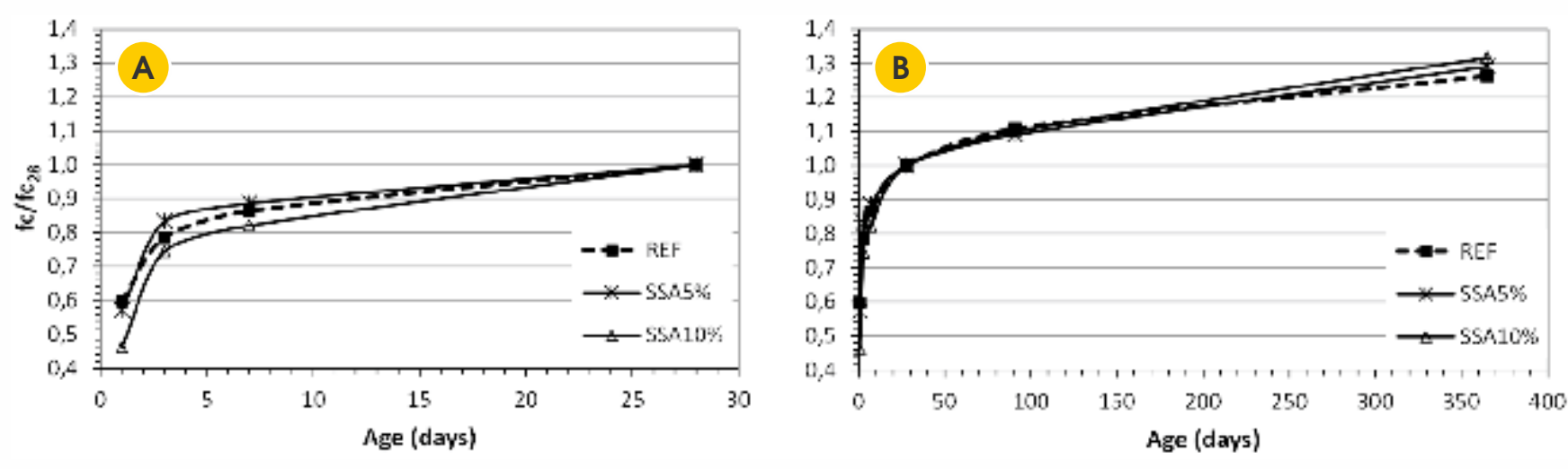
Table 3 - Compressive resistance (MPa) for REF, SSA5\% and SSA 10\% mixture

\begin{tabular}{cccccccc} 
& \multicolumn{7}{c|}{ fc (MPa) - C.V. (\%) } \\
Mixiures & 1 day & 3 days & 7 days & 28 days & 91 days & 365 days \\
\hline REF & $35,5-0,72$ & $46,7-1,98$ & $51,4-3,95$ & $59,5-3,62$ & $65,9-0,85$ & $75,1-2,99$ \\
SSA5\% & $33,1-2,45$ & $48,3-1,00$ & $51,4-3,33$ & $58,0-2,28$ & $63,2-0,77$ & $74,8-2,32$ \\
SSA10\% & $23,7-1,52$ & $38,2-0,59$ & $42,1-0,48$ & $51,3-3,54$ & $56,4-2,97$ & $67,5-3,19$ \\
\hline
\end{tabular}

\section{Table 4 - Pore size distribution of REF, SSA $5 \%$ and SSA $10 \%$ mixture}

\begin{tabular}{|c|c|c|c|c|}
\hline \multirow[b]{2}{*}{ Mixtures } & \multicolumn{4}{|c|}{ Volume of mercury (\%) } \\
\hline & $\begin{array}{c}\text { Small capillaries } \\
(0,0025<\varphi<0,01 \mu \mathrm{m})\end{array}$ & $\begin{array}{l}\text { Medium capillaries } \\
(0,01<\varphi<0,05 \mu \mathrm{m})\end{array}$ & $\begin{array}{l}\text { Large capillaries } \\
(0,05<\varphi<10 \mu \mathrm{m})\end{array}$ & $>10,0 \mu \mathrm{m}$ \\
\hline REF & 9,83 & 63,48 & 21,91 & 4,78 \\
\hline SSA5\% & 19,47 & 48,23 & 28,10 & 4,20 \\
\hline SSA $10 \%$ & 16,40 & 48,99 & 30,56 & 4,04 \\
\hline
\end{tabular}

associated with increased volume of large capillaries contained in these samples. The presence of a greater amount contributes as propagator of cracks, influencing the material behavior in the elastic linear phase and a decrease of this parameter.

With respect to the Poisson's ratio and tensile strength by diametrical compression of mixtures containing ash, it can be assumed that the presence of SSA practically has no influence on these properties.

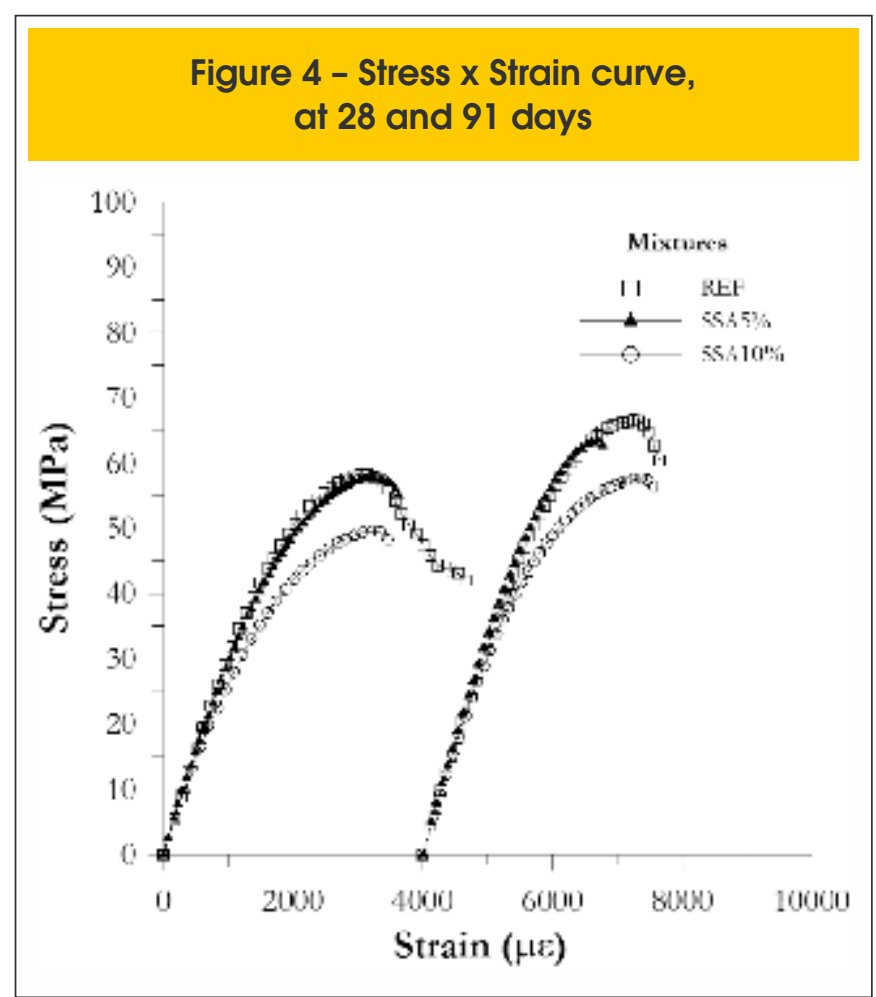

For the physical properties, shown in Table 6 , there is a proximity of the water absorption results due to the variation coefficient obtained. However, the voids index and absorptivity (stage 1) to the mixtures containing SSA were lower than the reference. This fact shows that the ash presence interfered with the interconnectivity between the pores, which difficults the water percolation, because as the SSA level in the concrete increased, there was a reduction in the values for these properties in relation to the reference. That is, there has been a change in the pore structure of the material, as shown by mercury intrusion porosimetry test (Table 4).

The results show a decrease in pore volume between 0.01 and $0.05 \mathrm{~mm}$ (capillary medium) and a consequent increase in small capillaries $(0.0025<\phi<0.01 \mathrm{~mm})$, responsible for the refinement of the microstructure of these concretes, a factor that directly interfered in pore interconnectivity.

This characteristic was also reflected in the durability. The REF and SSA5\% mixtures, according to the classification given by ASTM C 1202 [35], were considered low ??penetration of chloride ions and the SSA $10 \%$ mixture as very low penetration to chloride ions (Figure 5). This demonstrates that the presence of SSA in concrete provided a reduction of electric charge of respectively $30 \%$ and $46 \%$ for concentrations of $5 \%$ and $10 \%$ compared to the reference mixture.

\section{Conclusions}

From the results obtained, it can be said that SSA has influenced more significantly the physical properties and durability when compared to mechanical properties. That is, its presence has changed the microstructure of pores of the concrete containing this residueand thus reducing its connectivity.

Regarding the content, mixtures with $5 \%$ ash cement replacement showed a better behavior.

With regard to compressive strength, the mixtures SSA5\%, at ages 
Table 5 - Elasticity modulus (E), Poisson's index ( $v$ ) and Tensile strength by diametrical compression (Rtcd) of REF, SSA $5 \%$ and SSA $10 \%$ mixture

\begin{tabular}{|c|c|c|c|c|}
\hline \multirow{2}{*}{ Mixtures } & \multicolumn{2}{|c|}{ E (GPa) - C.V. (\%) } & \multirow{2}{*}{$v(\mathrm{MPa})-\mathrm{C} . \mathrm{V} .(\%)$} & \multirow{2}{*}{ Rtcd (MPa) - C.V. (\%) } \\
\hline & 28 days & 91 days & & \\
\hline REF & $31,5-1,87$ & $32,6-1,92$ & $0,20-7,42$ & $4,8-11,53$ \\
\hline SSA5\% & $30,5-1,98$ & $33,8-1,50$ & $0,18-1,79$ & $4,7-13,64$ \\
\hline SSA10\% & $28,1-2,79$ & $31,8-2,70$ & $0,20-5,18$ & $4,7-12,35$ \\
\hline
\end{tabular}

Table 6 - Physical properties of REF, SSA5\% and SSA 10\%

\begin{tabular}{|c|c|c|c|c|c|}
\hline \multirow{2}{*}{ Mixtures } & \multirow{2}{*}{$\begin{array}{c}\text { Immersion } \\
\text { water absorption } \\
(\%)-\text { C.V. }(\%)\end{array}$} & \multirow{2}{*}{$\begin{array}{l}\text { Voids index } \\
(\%)-\text { C.V. (\%) }\end{array}$} & \multirow{2}{*}{$\begin{array}{l}\text { Specific weight } \\
\left(\mathrm{g} / \mathrm{cm}^{3}\right) \text { - C.V. (\%) }\end{array}$} & \multicolumn{2}{|c|}{ Absortivity $\left(\mathrm{g} / \mathrm{cm}^{2} . \mathrm{f}^{1 / 2}\right)$} \\
\hline & & & & Stage 1 & Stage 2 \\
\hline REF & $1,61-3,70$ & $3,80-3,55$ & $2,36-0,19$ & 0,0332 & 0,0096 \\
\hline SSA5\% & $1,54-3,88$ & $3,64-3,77$ & $2,35-0,18$ & 0,0217 & 0,0089 \\
\hline SSA $10 \%$ & $1,54-9,49$ & $3,61-9,15$ & $2,34-0,40$ & 0,0256 & 0,0100 \\
\hline
\end{tabular}

of 1, 28, 91 and 365 days and SSA10\% (all ages)showed lower results than those of the reference, and this was attributed to the increase in pore volume between $0.05<\phi<10 \mu \mathrm{m}$. This behavior shows that the ash served as thin?? a thinner ?and not as a binder. The physical effect was more significant than the chemical effect, as there was no improvements in this parameter. The same is true for the elasticity modulus properties, tensile strength by diametrical compression and Poisson's ratio, that is, there was no influence of ash, and the results are near to those of the reference.

The absorption of water by immersion, void ratio and absorptivity of mixtures containing ash were lower than those of the reference. This behavior can be explained by the refinement of the pore structure of the concrete containing SSA, according to the mercury intrusion porosimetry test.

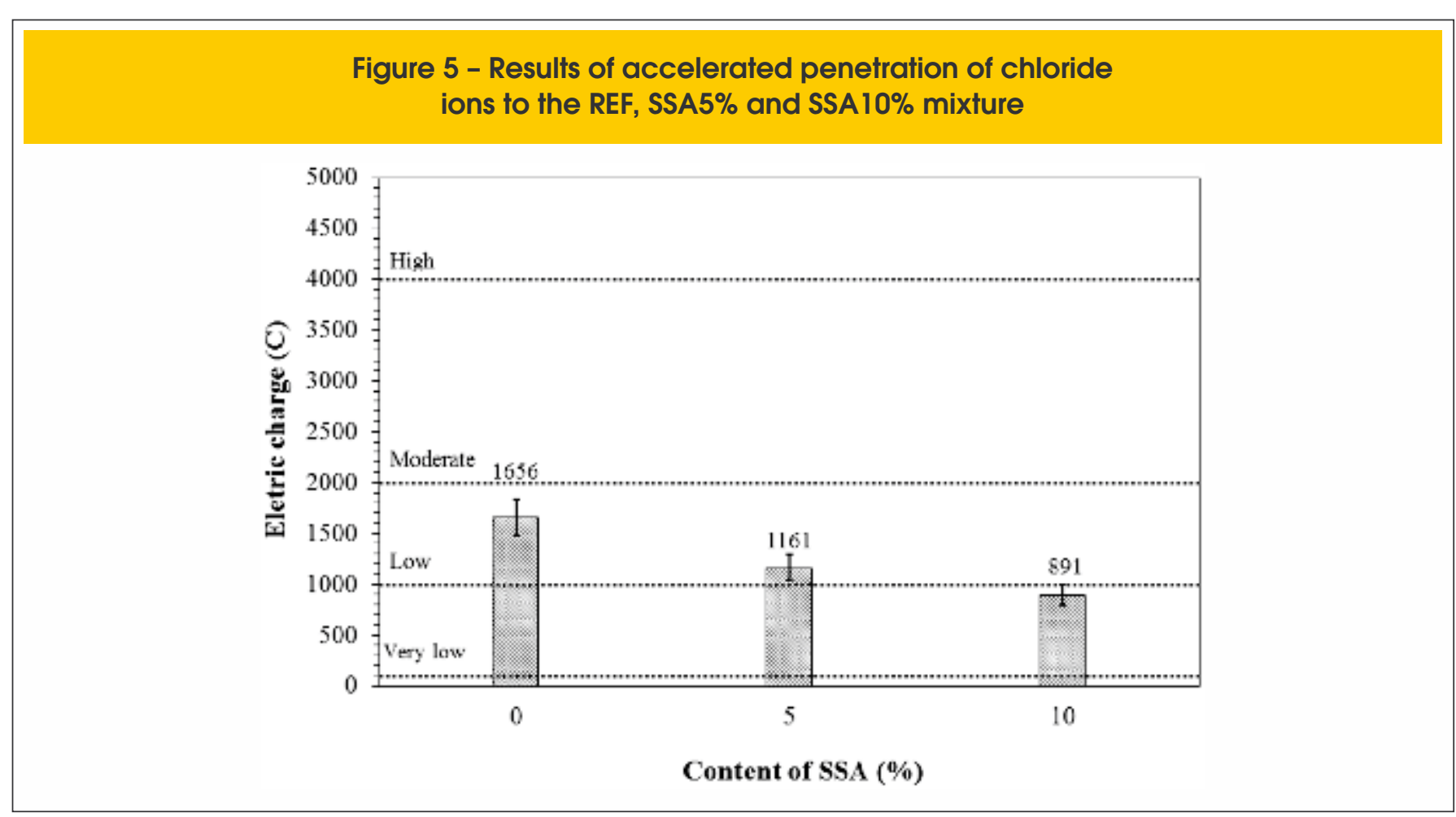


The electric charge of mixtures with $5 \%$ and $10 \%$ of SSA were lower than the reference, these being classified as low and very low to the penetration of chloride ions, respectively.

Therefore, it can be said that the presence of ash provided a refinement in the pore structure of the concrete, hindering the percolation of aggressive external agents.. This fact contributes to the improvementof durability properties and consequent increases the lifespan of this material.

\section{Acknowledgements}

The authors acknowledge the Coordenação de Aperfeiçoamento de Pessoal de Nivel Superior (CAPES) by the first author Doctoral scholarship.

\section{References}

[1] PEDROZA et al. Produção e tratamento do lodo de esgoto - Uma revisão. Revista Liberato. Novo Hamburgo. v.2, n.5, 2010; p.147-157.

[2] SAITO, M. L. O uso do lodo de esgoto na agricultura: precauções com os contaminantes orgânicos. Embrapa - Meio Ambiente. Jaguariúna. 2007; 30p.

[3] FONTES, C. M. A. Potencialidades da cinza de lodo de estações de tratamento de esgotos como material suplementar para a produção de concretos com cimento Portland. Dissertação (Mestrado). Programa de Engenharia Civil da Universidade Federal do Rio de Janeiro. Rio de Janeiro, 2003; 143 p.

[4] BORGES, F., SELLIN, N., MEDEIROS, S. H. W. Caracterização e avaliação de lodos de efluentes sanitário e Industrial como biomassa na geração de energia. Ciência \& Engenharia. v. 17. 2008; p. 27-32.

[5] GONÇALVES, J. E., SARTORI, M. M. P., LEÃO, A. L. Energia de briquetes produzidos com rejeitos de resíduos sólidos urbanos e madeira de Eucalyptus grandis. Revista Brasileira de Engenharia Agrícola e Ambiental. v. 13. n. 5. 2009; p.657-661.

[6] LIMA, J.F. Avaliação da incorporação de cinzas de lodo de esgotos como adição mineral em concretos de cimento Portland. Dissertação (Mestrado). Universidade Federal do Rio Grande do Norte. Natal. 2013; 96p.

[7] Cyr, M., Coutand, M., Clastres, P. Technological and environmental behavior of sewage sludge ash (SSA) in cement-based materials. Cement and Concrete Research. v. 37, 2007; p.1278-1289.

[8] PAN, S.C., TSENG, D.H., LEE, C., , "Influence of yhe fineness of sewage sludge ash on the mortar properties", $\mathrm{Ce}$ ment and Concrete Research, v. 33, n. 11 (Nov), pp. 17491754, 2003.

[9] Baeza-Brotons, F. et al. Portland cement systems with addition of sewage sludge ash. Application in concretes for the manufacture of blocks. Journal of Cleaner Production. v. 82. pp. 112-124. 2014

[10] CYR, M., IDIR, R., ESCADEILLAS, G. Use of metakaolin to stabilize sewage sludge ash and municipal solid waste incineration fly ash in cement-based materials. Journal of Hazardous Materials. v.243. 2012; 193-203p.

[11] FONTES, C. M. A. Utilização das Cinzas de Lodo de Esgoto e de Resíduo Sólido Urbano em Concretos de Alto Desempenho. Tese (Doutorado). Programa de Engenharia Civil da
Universidade Federal do Rio de Janeiro. Rio de Janeiro. 2008; 273p.

[12] TAY, J. H, SHOW, K. Y., HONG, S. Y. Potential Reuse of Wastewater Sludge for Innovative Aplications in Construction Industry. Bulletin of the College of Engineering. N.T.U. n. 86. 2002; p.103-112.

[13] GEYER, A. L. B. Contribuição ao estudo da disposição final e aproveitamento da cinzade lodo de estações de tratamento de esgotos sanitários como adição ao concreto. Tese de Doutorado. Universidade Federal do Rio Grande do Sul. Porto Alegre. 2001; 238p

[14] AL SAYED, M. H., MADANY, I. M., BUALI, A. R. M., Use of Sewage Sludge Ash in Asphaltic Paving Mixes in Hot Regions. Construction and Building Materials. v. 9. n.1. 1994; p. 19-23.

[15] XU, G., LIU, M., LI, G. Stabilization of heavy metals in lightweight aggregate made from sewage sludge ash. Journal of Hazardous Materials. v.260. 2013; p.74-81.

[16] BAEZA-BROTONS, F., GARCÉS, P., PAYÁ, J., SAVAL, J. $M$. Portland cement systems with addition of sewage sludge ash. Application in concretes for the manufacture of blocks. v.82. 2014; p.112-124.

[17] CHEESEMAN, C. R., VIRDI, G. S. Properties and microstructure of lightweight aggregate produced from sintered sewage sludge ash. Resources, Conservation and Recycling. v. 45. 2005; p. 18-30.

[18] RÉMOND, S., PIMIENTA, P., BENTZ, D. P. Effects of the incorporation of Municipal solid waste incineration fly ash in cement pastes and mortars I. Experimental study. Cement and Concrete Research. v. 32. 2002; p. 303-311.

[19] MORALES, G., AGOPYAN, V. Caracterização do agregado leve obtido a partir do lodo de esgoto da cidade de Londrina. Boletim Técnico da Escola Politécnica da USP. BT/PCC/64. 1992; p. 1-20.

[20] BROSCH, C.D. Fabricação de agregado leve a partir do lodo de esgoto. In: Congresso Brasileiro de Engenharia Sanitária. Rio de Janeiro. 1975; p. 103-107.

[21] CHEN, L., LIN, D. F. Applications of sewage sludge ash and nano-SiO2 to manufacture tile as construction material. Construction and Building Materials. v.23. 2009; p.3312-3320.

[22] TAY, J. H. Sludge Ash as Filler for Portland Cement Concrete. Journal of Environmental Engineering. v. 113. n. 2. 1987; p.345-351.

[23] TAY, J.H. Potential Use of Sludge Ash as Construction Material. Elsevier Science Publishers B.V. v. 13. 1986; p. 53-58.

[24] ASSOCIAÇÃO BRASILEIRA DE NORMAS TÉCNICAS. Materiais pozolânicos - Especificações. NBR 12653, Rio de Janeiro, 1992.

[25] ASSOCOAÇÃO BRASILEIRA DE NORMAS TÉCNICAS. Materiais pozolânicos - Determinação de atividade pozolânica com cimento Portland - Índice de atividade pozolânica com cimento. NBR 5752. Rio de Janeiro, 1992.

[26] ASSOCIAÇÃO BRASILEIRA DE NORMAS TÉCNICAS. Lixiviação de Resíduos - Procedimento. NBR 10005, Rio de Janeiro, 2004.

[27] ASSOCIAÇÃO BRASILEIRA DE NORMAS TÉCNICAS. Solubilização de Resíduos - Procedimento. NBR 10006, Rio de Janeiro, 2004. 
[28] ASSOCIAÇÃO BRASILEIRA DE NORMAS TÉCNICAS. Resíduos Sólidos - Classificação. NBR 10004, Rio de Janeiro, 2004.

[29] AMERICAN SOCIETY FOR TESTING AND MATERIALS. Test for static modulus os elasticity and poisson's ratio of concrete in compression. ASTM C 469, U.S.A., 1994.

[30] INTERNATIONAL SOCIETY FOR ROCK MECHANICS (IESA). Suggested methods for determining tensile strength of rock materials. v.3, 1977.

[31] ASSOCIAÇÃO BRASILEIRA DE NORMAS TÉCNICAS. Argamassa e concreto endurecido - Determinação da absorção de água por imersão - Índice de vazios e massa específica. NBR 9778, Rio de Janeiro, 2005.

[32] ASSOCIAÇÃO BRASILEIRA DE NORMAS TÉCNICAS. Argamassa e concreto endurecido - Determinação da absorção de água por capilaridade. NBR 9779, Rio de Janeiro, 1995.

[33] HALL, C. Water absortion of mortars and concrets: a review. Magazine of concrete in Research, v.41, n. 147,1989; p. 51-61.

[34] GONÇALVES, J.P. Argila calcinada como substitutivo parcial do cimento Portland: uma alternativa sustentável para indústria do concreto. Exame de Qualificação, (Doutorado). Universidade Federal do Rio de Janeiro. Rio de Janeiro, RJ. Brasil. 2003

[35] ALIGIZAKI, K. K., Pore structure of cement-based materials: testing, interpretation and requirements. Series Modern concrete technology, v. 12, New York. Ed. Britsh Library. 2006.

[36] AMERICAN SOCIETY FOR TESTING AND MATERIALS. Electrical Indication of concrete's ability to resist chloride ion penetration. ASTM C 1202, U.S.A., 1997.

[37] SILVEIRA, M. L. A., ALLEONI, L. R. F., GUILHERME, L. R. G. Biosolids and heavy metals in soils. Scientia Agricola. v. 60, n. 4, 2003; p. 793-806.

[38] MERLINO, L. C. S. Bário, cádmio, cobre e chumbo em plantas de milho e em latossolo que recebeu lodo de esgoto por onze anos. Dissertação (Mestrado). Faculdade de Ciências Agrárias e Veterinárias. Universidade Estadual Paulista. Jaboticabal. 2010; 92p. 